\title{
EFEKTIVITAS PENGGUNAAN GOOGLE CLASSROOM SEBAGAI MEDIA PEMBELAJARAN JARAK JAUH PADA PESERTA DIDIK KELAS 6 SD NEGERI JARAKAN DI MASA PANDEMI COVID-19
}

\author{
Winda Nur Febrianti ${ }^{1}$, Aninditya Sri Nugraheni ${ }^{2}$
}

\begin{abstract}
${ }^{1}$ Fakultas Ilmu Tarbiyah dan Keguruan, UIN Sunan Kalijaga Yogyakarta, Jl. Laksda Adisucipto, Papringan, Caturtunggal, Depok, Sleman, Daerah Istimewa Yogyakarta, windanurfebrianti1502@gmail.com

${ }^{2}$ Fakultas Ilmu Tarbiyah dan Keguruan, UIN Sunan Kalijaga Yogyakarta, Jl. Laksda Adisucipto, Papringan, Caturtunggal, Depok, Sleman, Daerah Istimewa Yogyakarta, aninditya.nugraheni@uin-suka.ac.id
\end{abstract}

\begin{abstract}
This study aims to determine the effectiveness of the development of learning outcomes of grade 6 students through the google classroom media at SD N Jarakan during the Covid-19 pandemic. In addition, this research also aims to find out how the development of student learning outcomes through distance learning with google classroom and to find out what obstacles are encountered in learning using the google classroom media. This research uses qualitative methods with qualitative descriptive research and literature study. The subjects in this study were 6th grade students of SD N Jarakan. The object in this study is the effectiveness of the development of student learning outcomes in grade 6 students during the Covid-19 pandemic using Google Classroom media. Data collection techniques through observation, interviews, and field notes results. The results of this study indicate that there is an increase in online student learning with Google Classroom. Although there are obstacles in its use, this media is sufficient to convey learning. This is because Google Classroom is considered to be the best platform of the day for online learning.
\end{abstract}

Keyword : Learners, Distance Learning, and Google Classroom.

\begin{abstract}
ABSTRAK
Penelitian ini bertujuan untuk mengetahui efektivitas perkembangan hasil belajar peserta didik kelas 6 melalui media google classroom di SD N Jarakan pada masa pandemi covid-19. Selain itu, penelitian ini juga bertujuan untuk mengetahui bagaimana perkembangan hasil belajar peserta didik melalui pembelajaran jarak jauh dengan google classroom serta mengetahui kendala apa saja yang ditemui dalam pembelajaran menggunakan media google classroom tersebut. Penelitian ini menggunakan metode kualitatif dengan jenis penelitian deskriptif kualitatif dan studi pustaka. Subjek dalam penelitian ini yaitu siswa kelas 6 SD N Jarakan. Objek dalam penelitian ini ialah efektivitas perkembangan hasil belajar peserta didik pada siswa kelas 6 di masa pandemi covid-19 dengan media Google Classroom. Teknik pengumpulan data melalui observasi, wawancara, dan hasil catatan lapangan. Hasil penelitian ini menunjukkan bahwa adanya peningkatan dalam pembelajaran peserta didik secara daring dengan Google Classroom. Walaupun terdapat kendala dalam penggunaannya, tetapi dengan media ini dirasa cukup untuk menyampaikan permbelajaran. Hal ini karena Google Classroom dianggap sebagai platform terbaik dimasa sekarang dalam pembelajaran secara daring.
\end{abstract}


Kata kunci : Peserta didik, Pembelajaran Jarak Jauh, dan Google Classroom.

How to Cite: Winda, W. N. F., \& Aninditya, A. S. N. (2021). EFEKTIVITAS PENGGUNAAN GOOGLE CLASSROOM SEBAGAI MEDIA PEMBELAJARAN JARAK JAUH PADA PESERTA DIDIK KELAS 6 SD NEGERI JARAKAN DI MASA PANDEMI COVID-19. Bahtera Indonesia; Jurnal Penelitian Bahasa Dan Sastra Indonesia , 6(2), 120134. https://doi.org/10.31943/bi.v6i2.108

DOI: $\underline{\text { https://doi.org/10.31943/bi.v6i2.108 }}$

\section{PENDAHULUAN}

Adanya Covid-19 di Indonesia membuat Kementrian Pendidikan dan Kebudayaan RI (Permendikbud) memberlakukan pembelajaran jarak jauh (PJJ). Hal ini terhitung sejak awal April 2020 sesuai dengan Permendikbud Nomor 103 Tahun 2013 tentang Penyelenggaraan Pendidikan Jarak Jauh pada pendidikan Indonesia. Pendidikan jarak jauh dapat diartikan sebagai Pendidikan formal berbasis lembaga dimana peserta didik dan infrastrukturnya terpisah lokasinya sehingga perlu komunikasi sebagai penghubung diantara keduanya beserta sumber daya lainnya. Di Kabupaten Bantul pun bupati Bantul sudah mengeluarkan surat edaran Nomor 423/01608 mengenai perpanjangan masa pembelajaran jarak jauh bagi peserta didik pada masa darurat bencana corona virus disease 2019 di lingkungan Pendidikan kabupaten Bantul. DalamPJJ ini guru tidak perlu bertemu dengan peserta didik dalam aktivitas belajar mengajar. Hal ini dikarenakan tidak diperbolehkan aktivitas tatap muka antara peserta didik dan pengajar.

Selama pandemi Covid-19 ini, pembelajaran sekolah tetap dilakukan dengan berbagai media dan sarana yang ada. Hal ini juga dipandu oleh guru dalam pembelajarannya. Dalam pelaksanaannya guru pun juga harus mencapai target kinerja. Hal ini sesuai dengan peraturan perundangundangan tentang kedisiplinan pegawai. Guru pun harus bisa mendesain pembelajaran jarak jauh ini dengan semenarik mungkin agar tidak membosankan. Selain itu guru juga dapat memanfaatkan berbagai aplikasi pembelajaran yang menunjang pembelajaran jarak jauh.

Perkembangan dalam bidang pengetahuan dan pendidikan mengalami peningkatan signifikan dengan teknologi yang ada. Hal ini terbukti dari hasil survey dari Asosiasi Penyelenggara Jaringan Internet Indonesia tahun 2016 bahwa pengguna 
internet mencapai 132,7 juta. Dengan jumlah total keseluruhan penduduk Indonesia 256,2 juta. Usia Sekolah Dasar (SD) ialah masa dari kelanjutan usia taman kanak-kanak. Dalam aspek perkembangannya, tentu tidak lepas dari adanya dukungan dari lingkungan itu sendiri, seperti lingkungan keluarga, sekolah, masyarakat, dan teman sebayanya. Selain itu, sarana dan prasarana yang ada juga sangat mewadahi anak-anak dalam proses perkembangannya. Dengan adanya stakeholders dapat memberikan pengaruh pada kemauan anak untuk belajar sehingga pembelajarannya pun juga efektif. Dilihat pada anak-anak SD N Jarakan khususnya kelas 6, Kecamatan Sewon, Kabupaten Bantul menunjukkan adanya semangat belajar yang tinggi walaupun melalui sistem daring (dalam jaringan) dimasa pandemi covid-19.

Setiap harinya pada jam belajar sekolah yang sekarang menjadi di rumah masing-masing, setiap anak mengerjakan tugas yang diberikan guru melalui berbagai media, seperti media WAG, Google Classroom, dan Google Form. Anak-anak sangat antusias dan giat dalam mengerjakan latihan-latihan yang diberikan dan kemudian dikirimkan kembali kepada gurunya untuk dinilai dan dimasukkan kedalam lembar penilaian sebagai hasil belajar peserta didik selama di rumah. Hal ini membuktikan adanya keseimbangan antara teknologi dengan ilmu pengetahuan.

$$
\text { Pembelajaran online ini }
$$

membutuhkan dari berbagai macam perangkat seperti gawai/ smartphone, data internet, dll. Penggunaannya memiliki konstribusi yang sangat besar dalam pencapaian pembelajarannya. Peserta didik bisa menggunakan handphone nya sebagai media belajar secara online/ daring. Tidak perlu memaksakan diri untuk menggunakan laptop ataupun komputer. Sistem belajar peserta didik kelas 6 ini menggunakan aplikasi Google Classroom. Dimana aplikasi Google Classroom ini merupakan platform pembelajaran yang dikembangkan oleh google yang bertujuan menyederhanakan pembuatan, pendistribusian dan penetapan tugas tanpa kertas (Wikipedia, 2017). Google Classroom ini merupakan aplikasi multiplatform yang sangat mudah diakses dan digunakan oleh pengguna. Google Classroom ini merupakan media pembelajaran e-learning dengan WebCT. Hal ini memungkinkan terciptanya sebuah kelas dalam dunia maya atau online. Google Classroom ini diharapkan dapat membantu proses pembelajaran selama pandemi dimana saja dan kapan saja. Google classroom bertujuan untuk mempermudah pembelajaran dikelas maya.

Caranya pun tentu sangat mudah. Guru dan peserta didik dapat mengunjungi 
situs https://classroom.google.com atau bisa dengan mengunduh aplikasinya di Google Playstore di android atau komputer masingmasing. Penggunaannya pun juga tidak dipungut biaya sama sekali hanya saja harus memiliki paket data internet yang mewadai serta sinyal yang mendukung.

Guru dapat memberikan materi dengan aplikasi Google Classroom ini. Seperti image, voice note, google from, video, dll. Peserta didik pun dapat mengaksesmya setiap saat dan kapan saja. Hal ini tentu sangat membantu peserta didik dalam pembelajaran daring di rumah. Tak hanya itu, peserta didik dapat mencari informasi lebih luas lagi dengan media lainnya yang dapat menunjang pembelajaran dirumah.

Disinilah peran orang tua sangat dibutuhkan bagi masing-maisng peserta didik ketika belajar di rumah. Orang tua memiliki peran untuk mendidik anaknya sebagai pengganti guru saat di sekolah. Jikalau orang tua sibuk dengan pekerjaannya, maka mereka pun juga harus membagi waktunya untuk membimbing dan mendidik anak-anaknya selama belajar di rumah.

Faktanya masih banyak orang tua yang mengabaikan kewajiban tersebut. Masih banyak anak yang hanya bermain diluar rumah saja dan tidak mengerjakan tugas-tugas yang diberikan oleh gurunya. Hal ini tentu menimbulkan masalah bagi peserta didik dengan guru. Guru yang melihat anak didik nya seperti itu maka akan meninjau secara langsung ke rumahnya. Hal ini bertujuan untuk mengetahui hal-hal sebenarnya yang terjadi pada anak tersebut di rumah. Entah dari anaknya sendiri atau pun dari orang tuanya.

Kerja sama antara guru dengan orang tua juga perlu ditingkatkan kembali agar halhal yang tidak diinginkan dapat diminimalisir dengan baik. Terciptanya hubungan yang harmonis antara wali kelas dengan wali siswa tentu akan membuat sesuatu kondisi yang sangat menyenangkan. Dimana ikatan silaturahmi dan kekeluargaannya pun terjaga. Adanya jalinan komunikasi yang baik anatara keduanya untuk sama-sama membimbing anaknya menjadi generasi emas.

\section{METODE PENELITIAN}

Metode penelitian yang digunakan dalam penelitian ini ialah metode pengembangan berbasis deskriptif kualitatif yang didukung dengan study pustaka. Oleh karena itu dengan adanya aplikasi Google Classroom akan memvalidasi bagaimana perkembangan hasil belajar peserta didik selama pandemi Covid-19 ini dalam penggunaan Google Classroom. Data dari penelitian ini ialah hasil pekerjaan peserta didik yang diberikan kepada seluruh peserta 
didik melalui daring. Penelitian ini dilakukan dengan cara membuat kelas dengan aplikasi Google Classroom kemudian mengundang peserta didik untuk masuk kedalam kelas sesuai kode kelas atau surel yang telah dibagikan.

\section{Untuk mengunggah materi pembelajaran dapat dilakukan dengan memilih menu “ About” kemudian pilih “ Add Materials". Selain itu di Google Classroom ini dapat membuat sebuah pemberitahuan untuk peserta didik apabila materi sudah diupload dengan memilih " Stream” kemudian pilih “ Announcement”. Untuk menambahkan tugas yang akan diberikan bisa dengan klik “ Assigments" dan untuk menambahkan pertanyaan dengan memilih “Questions”.}

\section{Secara umum melalui Google} Classroom ini juga dapat dilihat melalui “ button" untuk melihat aktivitas bilamana peserta didik telah mengerjakan dan mengunggah hasil pekerjaan yang diberikan. Setelah peserta didik selesai mengerjkan dan mengunggah maka akan ada laporan "Done" pada halaman Google Classroom. Hal ini dilakukan tentu untuk mengetahui bagaimana perkembangan hasil belajar peserta didik dengan media Google Classroom di masa pandemi Covid-19 ini.

\section{HASIL DAN PEMBAHASAN}

Google Classroom merupakan aplikasi yang mudah dalam penggunaannya. Terdapat beberapa langkah dalam penggunaannya antara lain:

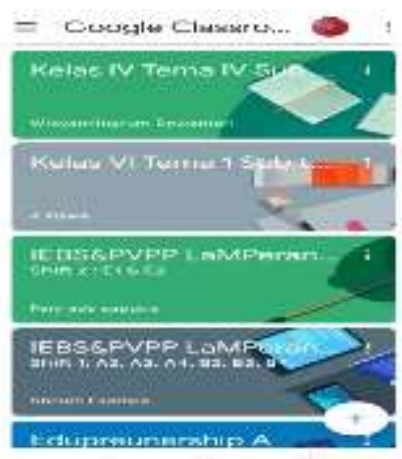

Gambar 1. Tampilan Kelas pada Aplikasi Google Classroom

Pada tampilan depan Google Classroom dapat dilihat beragam kelas yang sudah bergabung. Pada bagian pojok kanan bawah terdapat icon + . Dimana icon tersebut digunakan untuk bergabung kelas atau membuat suatu kelas.

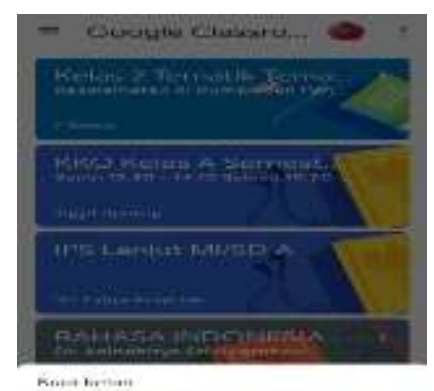




BAHTERA INDONESIA:

ISSN 2541-3252

Jurnal Penelitian Pendidikan Bahasa dan Sastra Indonesia

Vol. 6, No. 2 Sep. 2021
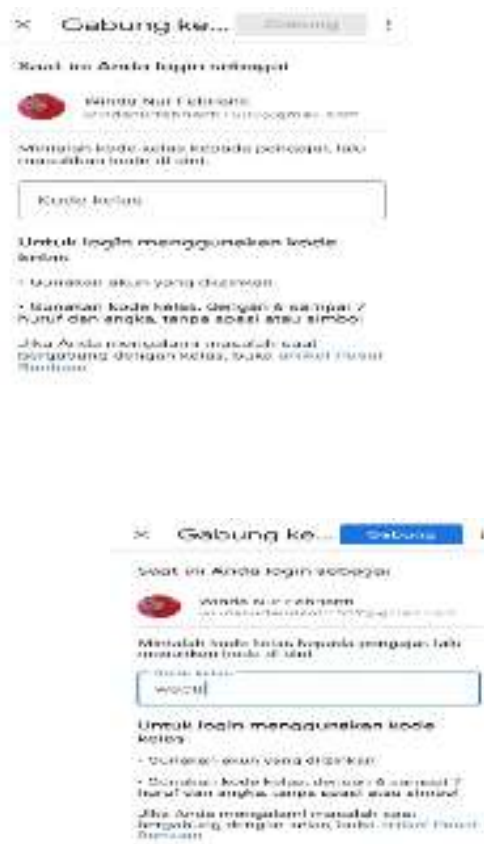

Gambar 2. Bergabung kelas atau membuat suatu kelas

Setelah memilih icon + maka akan keluar dua pilihan yaitu buat kelas dan gabung ke kelas. Sebagai contoh untuk bergabung kedalam kelas maka yang dipilih "Gabung ke kelas”. Setelah itu akan muncul tampilan pada bagian gambar tengah seperti diatas. Yang artinya anda disuruh memasukkan kode kelas agar bias bergabung dengan kelas tersebut. Setelah memasukkan kode kelas, tuliskan kodenya dan pilih gabung pada bagian pojok kanan atas. Secara otomatis sudah tergabung dalam kelas yang diikuti.

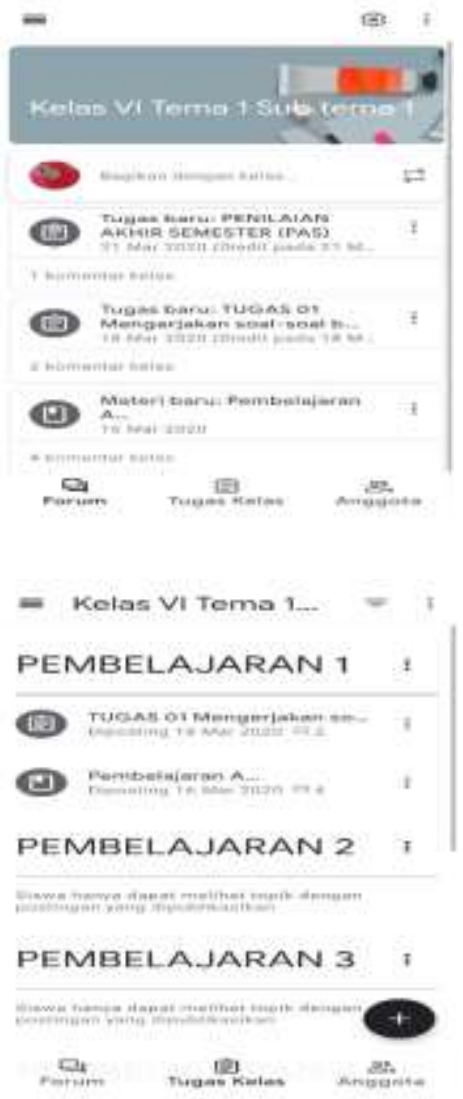

Gambar 3. Tampilan Kelas yang Diikuti. 


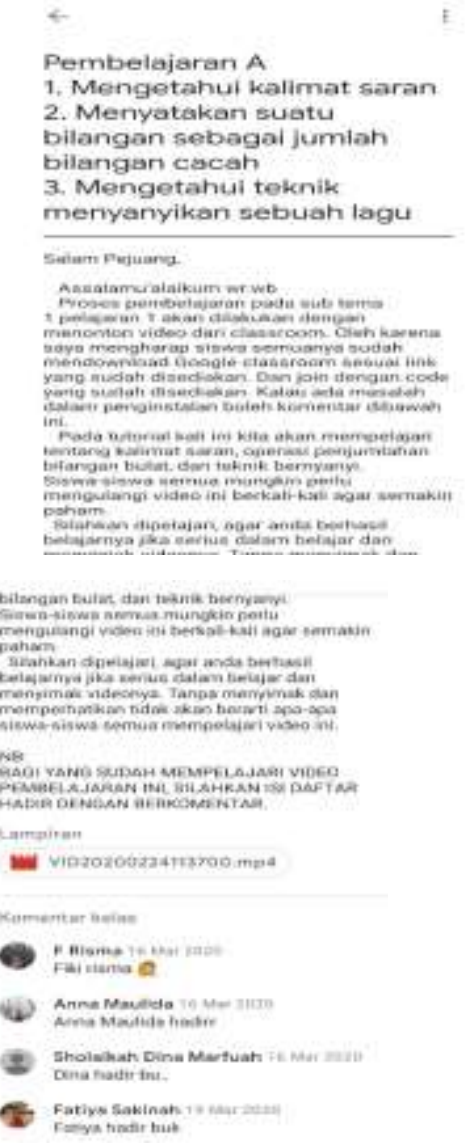

Gambar 4. Pembelajaran yang telah di upload guru.

Dalam kelas tersebut guru bias mengupload tugas dan pembelajaran yang akan diajarkan kepada peserta didiknya. Baik berupa image, video, google form, dll. Peserta didik pun bisa melihatnya kapan saja.
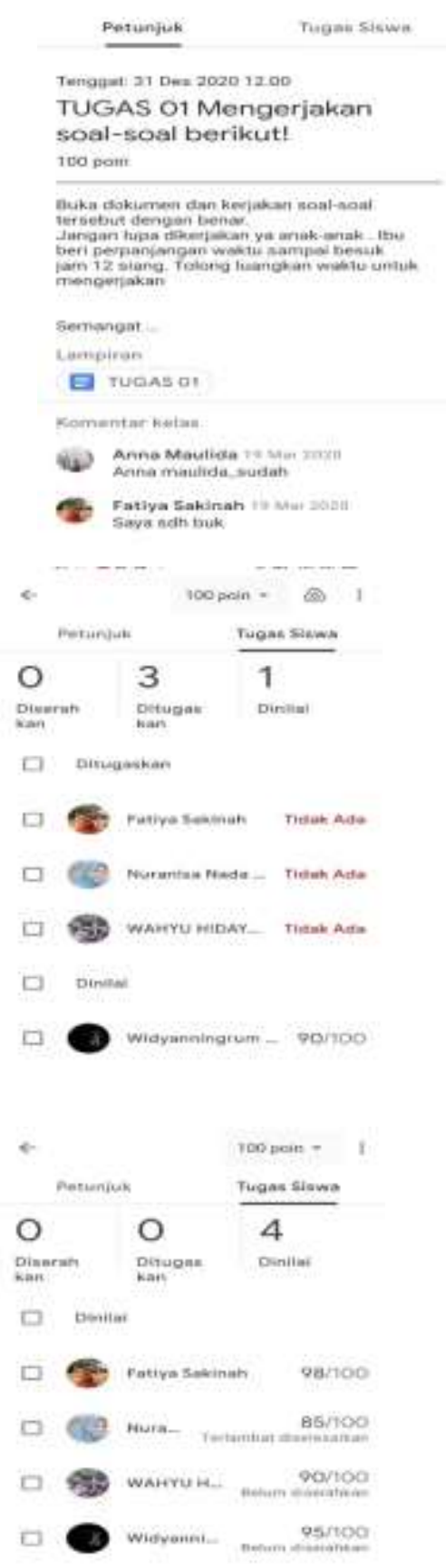

Gambar 5. Tugas yang diberikan guru.

Guru pun dapat membrikan tugas pada peserta didik dengan ketentuan yang telah disepakati. Biasanya guru memberikan batasan waktu dalam pengerjaan. Peserta 
didik yang telah mengerjakan pasti akan masuk datanya dan mendapat nilai dari guru tersebut. Begitupun sebaliknya jikalau peserta didik tersebut tidak mengerjakan maka akan terlihat pula.

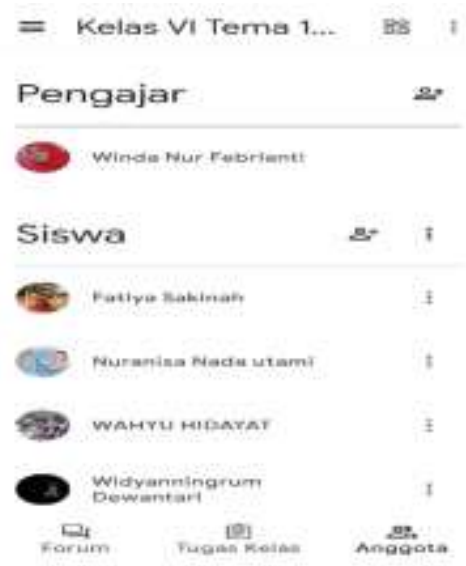

Gambar 6. Tampilan Anggota

Dari menu ini dapat dilihat pengajar dan peserta yang tergabung dalam kelas tersebut.

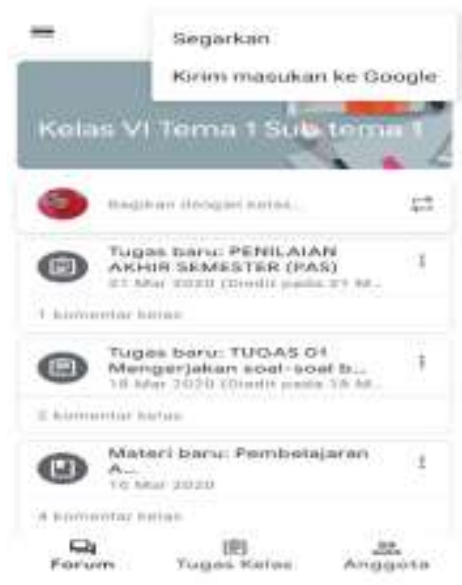

Gambar 7. Menu Segarkan

Dalam penggunaannya tidak dipungkiri adanya kendala sinyal. Jikalau terjadi masalah seperti itu, maka dapat dipilih icon "titik tiga" pada pojok kanan atas dan akan muncul menu pilihan seperti gambar 7 . Maka langsung dipilih “ segarkan”. Secara otomatis aplikasi ini akan memperbarui data yang baru masuk ataupun informasi lainnya. Selain itu, jika ada tugas masuk dari guru maka aka nada notifikasi dari email mengenai tugas baru yang masuk pada aplikasi Google Classroom.

Hasil pembahasan pada penelitian ini akan dibagi menjadi beberapa bagian untuk memfokuskan pada hasilnya.

\section{Tingkat kenyamanan pengguna}

Pada masa pandemi Covid-19 ini, banyak guru dan peserta didik yang menggunakan media pembelajaran dengan menggunakan Google Classroom. Dari hasil penelitian ini menunjukkan bahwa guru dan peserta didik sudah mengaplikasikan Google Classroom untuk pembelajaran jarak jauh (PJJ). Dengan adanya Google Classroom tentu terdapat beberapa manfaat seperti: media yang dapat memfasilitasi kelas virtual, dapat memberikan materi dan tugas dengan baik, materi yang disampaikan akan tersimpan secara otomatis, sistematis, dan terstruktur, semua mata pelajaran bisa masuk kedalam Google Classroom, dan dengan konteks pembelajaran daring Google Classroom lebih mampu mewadahi peserta didik dibandingkan dengan aplikasi messenger. Dari hasil penelitian didapatkan hasil bahwa tingkat kenyamanan 
peserta didik mencapai $73,9 \%$ dan peserta didik yang menyatakan ketidaknyamanannya berkisar $26,1 \%$ dengan adanya daring.

\section{Penggunaan Google Classroom}

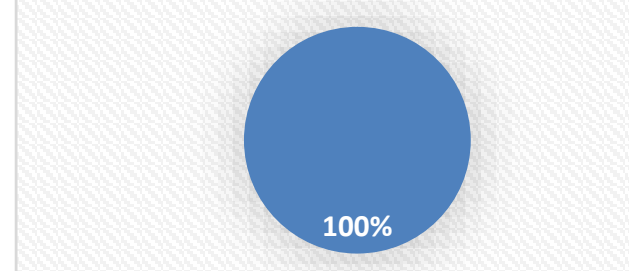

Diagram 1. Penggunaan Google Classroom

Dari diagram diatas terlihat jelas bahwa para responden menggunakan media Google Classroom untuk pembelajaran jarak jauh. Google Classroom ini merupakan platform terbaik untuk membackup pembelajaran secara daring . Hal ini disebabkan karena Google Classroom dapat mendukung kelas maya/ virtual, terintegrasi dan sinkron dengan platform yang lain sehingga dapat memudahkan pekerjaan. Dalam pembelajaran daring ini, Google Classroom sudah sangat efektif dengan catatan materi yang diupload tidak hanya sebatas file tetapi bisa juga berupa image, audio, video, kuis, google form, ataupun penggunaan platform lainnya yang tentu menarik dan interaktif.

Kemudian aplikasi Google Classroom ini dianggap sebagai aplikasi yang paling mudah dalam pengoperasiannya dan sudah terintegrasi pada google yang merupakan OS pada Hp android. Google Classroom dirasa sudah cukup efektif dan efisien dalam revolusi industri 4.0. Dalam penggunaan Google Classroom materi dan tugas tidak banyak memakan memori eksternal pada HP sehingga dapat mengoptimalkan pembelajaran.

2. Adaptasi peserta didik dengan media Google Classroom

Tidak semua peserta didik dapat melakukan dan memahami pembelajaran dengan konsisten. Hasil survei membuktikan bahwa $65,5 \%$ peserta didik dapat mengikuti dan beradaptasi dengan media pembelajaran tersebut. Selanjutnya 34,5\% lainnya merasa kurang dalam beradaptasi menggunakan Google Classroom. Dalam media pembelajaran Google Classroom hasil belajar peserta didik mengalami peningkatan dalam beberapa bidang.

Peningkatan hasil belajar ini dapat dilihat pada hasil belajar akademik yang memuat beberapa mata pelajaran dan keterampilan TIK yang dapat melatih dan menjadi kecakapan hidup sebagai bekal menghadapi tantangan global yang serba digital. Kemudian perkembangan pada peserta didik dapat dipantau dan dianalisis. Hal ini dapat disebut juga dengan simbiosis mutualisme dimana perkembangan belajar sangat baik dan penerimaan materi pelajaran yang berdampak 
pada hasil belajar maupun untuk mengembangkan keterampilan TIK yang sesuai dengan kecakapan abad 21.

Tetapi, ada pula guru yang beranggapan bahwa peningkatan hasil belajar tersebut karena adanya bantuan dari orang tua saat mengerjakan tugas maupun menggunakan media lain seperti Google, Chrome untuk membantunya dalam menjawab berbagai soal yang diberikan guru. Dalam beberapa sisi peserta didik lebih berkembang dalam literasi. Dalam kemampuan yang sesuai kurikulum baik SK dan KD nya lebih sulit diukur, karena hal ini banyak intervensi dari pihak orang tua secara langsung. Mayoritas anak yang unggul dalam hasil belajar, mereka mengalami penurunan dalam hasil bidang penyelesaian tugas.

\section{Efektivitas pembelajaran}

Efektivitas sendiri bisa diartikan sebagai suatu standar mutu pendidikan yang diukur demi tercapainya sebuah tujuan, atau ketepatan dalam mengelola suatu permasalahan dan kondisi (Rohmawati, 2015:16). Pada keefektifan pembelajaran ini menurut Soemosasmito (Al-Tabany, 2017:22) dikatakan efektif apabila memenuhi syarat-syarat utama diantaranya yaitu:

a. Presentasi pada saat KBM berlangsung.

b. Perilaku peserta didik terhadap tugas yang diberikan. c. Kemampuan siswa dengan kandungan materi yang diajarkan.

d. Menciptakan suasana belajar yang menarik, positif, dan tidak membosankan.

Guru memberikan tugas kepada peserta didik melalui Google Classroom melihat kondisi jam atau waktu. Seperti pada jam belajar ( antara pukul 07.30- 12.00 WIB), kemudian ada pula yang memberikan pelajaran tergantung pada kesepakatan antara guru, orang tua dengan peserta didik berkaitan dengan perangkat yang akan digunakan. Dimasa pandemi ini tidak memungkinkan untuk tatap muka dikelas. Dalam pengerjaannya pun peserta didik diberikan batasan waktu pengumpulan. Pemberian waktu ini pada setiap tugasnya berbeda-beda. Hal ini tergantung pada tingkat kesulitan dan kompleksitasnya. Tetapi ada pula yang membatasi waktu pengumpulan hingga jam 23.00 WIB. Tentu akan terlihat peserta didik yang telah mengumpulkan tugasnya dengan anak yang tidak mengumpulkan tugasnya dan terdapat timbal baliknya. Tujuan dari pemberian waktu ini agar peserta didik tidak terlalu stress tanpa mengesampingkan tanggung jawab dan kedisiplinan siswa.

Efektivitas ialah tingkat keberhasilan yang dapat dicapai. Media ini dianggap cukup efektif apabila mampu mewadahai dan 
memfasilitasi serta memenuhi kriteria. Hal itu tentu dapat dilihat dari pengaruh, perubahan, atau hasil yang tampak dan menonjol. Selain itu, pada Google Classroom ini dapat membuat peserta didik menjadi lebih aktif bertanya dan menanggapi pada kolom komentar. Peserta didik yang kurang aktif dikelas secara tatap muka kini menjadi aktif berkomentar. Hal ini menunjukkan adanya fasilitas yang mewadahaoi peserta didik. Tetapi nyatanya guru tidak dapat mengawasi secara langsung bahwa peserta didik tersebut benar-benar mengerjakan materi dengan sungguh-sungguh.

\section{Faktor-faktor yang mempengaruhi}

Perkembangan peserta didik tentu dipengaruhi oleh beberapa faktor. Seperti yang telah disampaikan oleh para guru dan peserta didik yang menjadi responden dalam penelitian ini. Terdapat beberapa faktor yang mempengaruhi, antara lain:

a. Faktor kesiapan perangkat dan fasilitas yang berupa smartphone dan kuota internet serta koneksi internet.

Hal yang paling vital dalam pembelajaran daring. Dikarenakan pembelajaran daring ini perlu adanya akses internet. Jika tanpa koneksi internet maka tidak dapat terinteraksi dengan sambungan. b. Kemauan peserta didik dalam menggunakan media berbasis TIK, dalam hal ini termasuk dengan keterampilan menggunakan media tersebut.

c. Kemandirian peserta didik.

Peserta didik mampu mengatur waktunya sehingga mereka dapat memanajemen waktu untuk kapan mengerjakan tugas dan mengurus dirinya sendiri.

d. Pendampingan orang tua di rumah.

Orang tua sangat dibutuhkan perannya dalam membantu anak dalam pembelajaran jarak jauh. Seperti harus bisa membagi-bagi waktunya untuk bekerja dan mendampingi anak belajar.

e. Pemahaman materi.

Peserta didik dapat melakukan pemahaman materi kapan saja. Karena pada Google Classroom ini materi yang telah dibagikan masih tetap tersimpan sehingga peserta didik dapat melihat kembali ulasan materi yang telah lalu. Selain itu terdapat beberapa peserta didik yang mengalami kesulitan dalam mempelajari materi-materi yang telah disampaikan guru melalui Google Classroom. Sekitar 84, 5\% peseerta didik tidak mudah dalam menjawab materi ataupun tugas dengan baik. Kemudian 15,5\% merspon dengan baik. Artinya dari hasil yang sedikit ini peserta didik 
menjawab dan dapat mempelajari materi yang ditugaskan.

f. Pencarian informasi lebih luas.

Berdasarkan hasil penelitian mayoritas peserta didik mengalami kesulitan dalam mengakses informasi yang ada. Sebanyak 69,9\% informasi yang sulit tidak ditemukan jawabannya. Kemudian sekitar $30,1 \%$ mendapat respon yang baik.

5. Kendala dalam pengaplikasian Google Classroom

Dari semua kelebihan dan manfaat Google Classroom tidak menutupi adanya kendala dan kekurangan pada Google Classroom. Kendala utama pada Google Classroom bagi yang belum memiliki fasilitas virtual, keterbatasan pengetahuan dalam mengelola dan memaksimalkan fitur-fitur yang ada. Tampilan pada Google Classroom tidak dapat diubah-ubah sesuai dengan keinginan kita. Dari sini kesulitan mengidentifikasi nama anak karena belum dapat diatur nama dalam seminggu yang tertera dalam email orang tua. Selain itu, ada pula dalam pembelajaran matematika, dalam pemberian soal latihan harus menambahkan add on untuk pengoperasian lainnya. Dalam penilaian tugas sistem yang digunakan harus sama dengan yang ditentukan. Seperti jawaban peserta didik harus sama persis dengan kunci jawaban sehingga dianggap benar jika berbeda sedikitpun baik dalam penggunaan huruf atau tanda baca maka jawaban tersebut akan dianggap salah.

Ada pula kendala yang paling besar ialah dari sumber daya manusia yaitu orang tua dan peserta didik diawal penggunaannya. Penolakan orang tua terhadap pengunaan Google Classroom sebagai media daring berkisar $85 \%$. Artinya hanya beberapa orang yang mendukung penggunaan Google Classroom ini. Hal ini dikarenakan latar belakang orang tua yang gagap teknologi. Namun dengan pendampingan melalui WAG atau whatsapp grup dan pemberian tutorial melalui video, akhirnya dalam kurun waktu yang singkat peserta didik sudah enjoy dalam penggunaannya. Dan terdapat pengakuan dari orang tua bahwa Google Classroom sangat memudahkan dalam belajar daring di rumah. Dengan bantuan dan peran orang tua yang terlihat untuk anaknya, maka anak akan menjadi lebih semangat dalam pembelajaran daring di rumah selama pandemi.

Selain itu, kendala lain yaitu dari data internet yang digunakan. Padahal biaya membeli data internet itu tergolong masih mahal dengan kondisi ekonomi masyarakat Indonesia. Hal itu terjadi karena perekonomian juga ikut berdampak akibat dari covid-19 ini. Ada pula sinyal dari internet yang digunakan terkadang trouble atau susah sinyal ditambah lagi ketika hujan. 


\section{Pemerintah sudah menyediakan} subsidi kuota untuk pendidikan. Tetapi hal itu dirasa masih kurang dengan tuntutan pembelajaran menggunakan media yang mahal data internet seperti zoom, melihat tayangan you tube, dll. Faktanya kuota subsidi pendidikan tersebut digunakan pada aplikasi tertentu seperti ruang guru, dll. Sehingga peserta didik yang tidak berlangganan tersebut data internet tersebut akan terbuang sia-sia dan secara otomatis tidak bisa digunakan lagi. Hal ini tentu merugikan sekali bagi para pengguna. Banyak peserta didik yang mengeluhkan terkait data internet tersebut.

\section{SIMPULAN}

Pandemi Covid-19 ini memang sudah banyak dampaknya pada dunia Pendidikan seperti pada jenjang Pendidikan TK, SD, SMP, SMA/MA, ataupun Perguruan Tinggi. Dalam rangka memutus tali penyebaran virus ini maka diadakan PJJ sesuai dengan surat edaran Kemendikbud. Dengan adanya Google Classroom ini dapat membantu peserta didik dalam menjalankan pembelajaran jarak jauh di rumah. Aplikasi ini sudah dianggap sebagai platform terbaik dalam pelaksanaan pembelajaran jarak jauh. Dengan kemudahan dalam mengakses aplikasi atau media ini membuat peserta didik lebih enjoy menjalankan pembelajaran. Selain itu, dengan adanya Google Classroom ini hasil belajar peserta didik pun juga meningkat. Hal ini tidak hanya pada mata pelajaran biasa, tetapi pada perkembangan TIK dimana pada aplikasi ini lebih mengembangkan skill TIK. Ada pula yang beranggapan bahwasanya peserta didik mendapatkan nilai yang lebih baik karena bantuan dari orang tua atau media lain yang dapat diakses seperti Chrome, Mozilla, dll.

Pada aplikasi Google Classroom ini pasti juga terdapat kelebihan, kekurangan, atau kendala dalam pelaksanannya. Seperti terbatasnya gawai dan minimnya kuota internet, dll. Tentu kelebihan dan kekurangan ini tidak hanya pada Google Classroom saja, tetapi aplikasi lain mungkin ada yang seperti ini.

Dalam PJJ orang tua pun wajib menjalankan perannya. Peran orang tua di rumah sebagai guru pengganti ketika anaknya belajar di sekolah. Orang tua juga harus bisa menciptakan suatu kondisi pembelajaran di rumah yang lebih menarik, kondusif sehingga mendukung mereka untuk lebih giat dalam belajar. Peserta didik pun harus tetap mengasah kemandiriannya dalam mennetukan dan membagi waktu yang ada selama belajar di rumah. Mulai dari penyusunan jadwal , kapan akan belajar, mengurus dirinya, dll. 


\section{DAFTAR PUSTAKA}

Ahmad , dkk. Efektivitas Pembelajaran Daring Dengan Menggunakan Google Classroom Pada Mata Pelajaran Matematika Di Madrasah Aliyah Darul Falah Batu Jangkih. Jurnal Pendidikan dan Kajian Islam (Online) Volume XIII, Nomor 1, Januari -Juni 2020: 69. (http://ejournal.kopertais4.or.id/sasamb o/index.php/elhikam/article/view/3895, diakses 25 Desember 2020).

Aidin, Zainal, dkk. Efektivitas Pembelajaran Jarak Jauh Pada Masa Pandemi Covid-19. Jurnal Ilmiah (Online), Oktober 2020:136. (https://journal.lppmunindra.ac.id/inde x.php/RDJE/article/view/7659, diakses 10 Desember 2020).

Artiyani, Rinni. Kajian Efektivitas Pembelajaran Jarak Jauh dalam Meningkatkan Pemahaman Matematika di SMKN 2 Palembang. Prosiding Seminar Nasional dan Diskusi Panel Pendidikan Matematika Universitas Indraprasta PGRI Jakarta: 3.

(http://proceeding.unindra.ac.id/index. php/DPNPMunindra/article/view/4704, diakses 30 Desember 2020).

Daheri, Mirzon. Efektivitas WhatsApp sebagai Media Belajar Daring. Jurnal Basicedu, (Online) Volume 4, Nomor 4, 2020: 777. (https://jbasic.org/index.php/basicedu/a rticle/view/445, diakses 28 Desember 2020).

Danang, Kharisma, dkk. Pengembangan Media Dan Strategi Pembelajaran Untuk Mengatasi Permasalahan Pembelajaran Jarak Jauh Di Pandemi Covid-19. Jurnal Pendidikan (Online) Vol. 4 N0. 3 Juni 2020 p-ISSN: 2548$883 X$ e-ISSN : 2549-1288: 53. (https://jurnal.unimed.ac.id/2012/inde x.php/jgkp/article/view/19472, diakses 25 November 2020).

Ekantini, Anita. Efektivitas Pembelajaran Daring pada Mata Pelajaran IPA di Masa Pandemi Covid-19 : Studi Komparasi Pembelajaran Luring dan Daring pada Mata Pelajaran IPA SMP. Jurnal Pendidikan Madrasah (Online), 2020: 188. (http://ejournal.uinsuka.ac.id/tarbiyah/index.php/JPM/arti cle/view/3511, diakses 26 Desember 2020).

Fitri, Mustika, dkk. Efektivitas Pembelajaran Daring Berbasis Media Sosial Facebook Dalam Meningkatkan Hasil Belajar. Jurnal of Science and Social Research (Online), Februari 2020: 75. (http://jurnal.goretanpena.com/index.p hp/JSSR/article/view/430, diakses 1 Desember 2020).

Giri,Anggy, dkk. Efektivitas Pembelajaran Jarak Jauh Terhadap Pembelajaran Siswa di SDIT Cendekia Purwakarta. Jurnal Pendidikan Dasar (Online) PISSN 2086-7433 E-ISSN 2549-5801 : 96.

(http://journal.unj.ac.id/unj/index.php/ jpd/article/view/15347, diakses 1 Januari 2021).

Gunawan, Fransiskus Ivan. Pengembangan Kelas Virtual Dengan Google Classroom Dalam Keterampilan Pemecahan Masalah ( Problem Solving ) Topik Vektor Pada Siswa SMK Untuk Mendukung Pembelajaran. Jurnal Prosiding Seminar Nasional Etnomatnesia (Online) ISBN: 978-6026258-07-6 : 341. (https://jurnal.ustjogja.ac.id/index.php/ etnomatnesia/article/view/2334/1296, diakses 2 Januari 2021).

Husna, Raudatul. Efektivitas Pembelajaran Turunan Pada Masa Pandemi Covid-19 Melalui Media Mobile Learning 
Ditinjau Dari Hasil Belajar Mahasiswa. Jurnal Numeracy (Online), Volume 7, Nomor 2, Oktober 2020: 326.

(https://ejournal.bbg.ac.id/numeracy/ar ticle/view/1187, diakses 5 Desember 2020).

Lailatul, Nurul, dkk. Efektivitas Pembelajaran Berbasis Daring: Sebuah Bukti Pada Pembelajaran Bahasa Inggris. Jurnal Pemikiran dan Penelitian Pendidikan (Online), Volume 17, Nomor 1, Juni 2019: 20. (https://journal.uinmataram.ac.id/index .php/tatsqif/article/view/667, diakses 20 Desember 2020).

Kemendikbud. ( www. Kemdikbud.go.id )

Kurniawan, Heru. Efektivitas Pembelajaran Problem Solving Dan Investigasi Terhadap Keterampilan Berfikir Kritis Matematis Berbantuan Google Classroom. Jurnal Pendidikan Surya Edukasi (Online), 2019:61. http://ejournal.umpwr.ac.id/index.php/s urya/article/view/3272, diakses 25 Desember 2020).

Maskar, Sugama \& Wulantina, Endah. Persepsi Peserta Didik terhadap Metode Blended Learning dengan Google Classroom. Jurnal Inovasi Matematika (Online), Volume 1, Nomor 2, 2019: 118. (https://www.researchgate.net/publicati on/335461755_Persepsi_Peserta_Didik terhadap_Metode_Blended_Learning dengan_Google_Classroom, diakses 25 November 2020).

Megawanti, Prianti dkk. Persepsi Peserta Didik Terhadap PJJ Pada Masa Pandemi Covid-19. Jurnal Ilmiah Kependidikan (Online), Volume 7, Nomor 2, Juli 2020: 81. (https://journal.lppmunindra.ac.id/inde x.php/Faktor/article/view/6411, diakses 28 Desember 2020).
Monitorir, Rodame. Dampak Pandemi Covid19 Terhadap Kepuasan Pembelajaran Jarak Jauh. Jurnal Inovasi Teknologi Pendidikan (Online). Volume 7, Nomor 1, April 2020:81. (https://journal.uny.ac.id/index.php/jitp /article/view/32771, diakses 21 Desember 2020.

Permata, Andira \& Bhakti, Yoga Budi. Keefektifan Virtual Class dengan Google Classroom dalam Pembelajaran Fisika Dimasa Pandemi Covid-19. Jurnal Inovasi Pendidikan Fisika dan Riset Ilmiah (Online), Mei 2020 Vol. 4 (1): 25. (http://journal.stkipnurulhuda.ac.id/ind ex.php/JIPFRI/article/download/669/3 56/, diakses 20 Desember 2020).

Roni, Acep. 2020. Efektivitas Implementasi Pembelajaran Daring ( Full Online) Dimasa Pandemi Covid-19 Pada Jenjang Sekolah Dasar Di Kabupaten Subang. Jurnal Ilmiah PGSD STKIP Subang (Online) Volume VI, Nomor 01, Juni :5. (http://journal.stkipsubang.ac.id/index. php/didaktik/article/view/120, diakses 28 Desember 2020).

Sadikin, Ali \& Hamidah, Afreni. Pembelajaran Daring di Tengah Wabah Covid-19. Jurnal Ilmiah Pendidikan Biologi (Online) Volume 6, Nomor 2, 2020: 218. ( https://onlinejournal.unja.ac.id/biodik/article/view/9 759, diakses 24 Desember 2020).

Sari, Isna Normalita. Pengaruh Penggunaan Google Classroom Terhadap Efektivitas Pembelajaran Mahasiswa Universitas Islam Indonesia. Skripsi. 2019:10.

(https://dspace.uii.ac.id/bitstream/handl e/123456789/13733/isna\%20normalita $\% 20$ sari.pdf? sequence $=1 \&$ isAllowed $=$ $\mathrm{y}$, diakses 5 Januari 2021). 
BAHTERA INDONESIA:

Savitri, Desy Irsalina. Penggunaan Pembelajaran $4.0 \quad$ Berbantukan Aplikasi Google Classroom dan Google Form dalam Mata Kuliah Ilmu Sosial Budaya Dasar. Jurnal Borneo Saintek (Online) Volume 2, Nomor 1, April 2019:

(http://jurnal.borneo.ac.id/index.php/bo rneo_saintek/article/view/632/, diakses 22 Desember 2020).

Surat edaran Bupati Kabupaten Bantul. corona.bantulkab.go.id ).

Wicaksono, Vicky Dwi \& Rachmadyanti,

Putri. Pembelajaran Blended Learning Melalui Google Classroom Di Sekolah Dasar. Jurnal Seminar Pendidikan PGSD UMS \& HDPGSDI Wilayah Jawa (Online) ISBN 978-602-70471-2-9 : 155. (https://publikasiilmiah.ums.ac.id/handle/ 11617/9144?show=full, diakses 20

November 2020). 